\title{
Discovery, characterization, and clinical development of the glucagon-like peptides
}

\author{
Daniel J. Drucker, ${ }^{1}$ Joel F. Habener, ${ }^{2}$ and Jens Juul Holst ${ }^{3}$ \\ 'Lunenfeld-Tanenbaum Research Institute, Mt. Sinai Hospital, University of Toronto, Toronto, Ontario, Canada. 'Laboratory of Molecular Endocrinology, Massachusetts Ceneral Hospital, Harvard University, \\ Boston, Massachusetts, USA. ${ }^{3}$ Novo Nordisk Foundation Center for Basic Metabolic Research, Department of Biomedical Sciences, University of Copenhagen, Copenhagen, Denmark.
}

\begin{abstract}
The discovery, characterization, and clinical development of glucagon-likepeptide-1 (GLP-1) spans more than $\mathbf{3 0}$ years and includes contributions from multiple investigators, science recognized by the $\mathbf{2 0 1 7}$ Harrington Award Prize for Innovation in Medicine. Herein, we provide perspectives on the historical events and key experimental findings establishing the biology of CLP-1 as an insulin-stimulating glucoregulatory hormone. Important attributes of GLP-1 action and enteroendocrine science are reviewed, with emphasis on mechanistic advances and clinical proof-of-concept studies. The discovery that GLP-2 promotes mucosal growth in the intestine is described, and key findings from both preclinical studies and the CLP-2 clinical development program for short bowel syndrome (SBS) are reviewed. Finally, we summarize recent progress in GLP biology, highlighting emerging concepts and scientific insights with translational relevance.
\end{abstract}

T he endocrine activity of the gastrointestinal tract has been studied for more than a century, with gut hormones such as secretin emerging from the seminal studies of Bayliss and Starling (1). The concept that the gut also controlled pancreatic islet secretions was supported by experiments demonstrating that administration of crude gut extracts lowered blood glucose in animals. The development of the insulin radioimmunoassay enabled the description of the incretin effect, namely that glucose administered into the gut potentiated insulin secretion to a greater extent than isoglycemic stimulation of insulin secretion achieved through i.v. glucose administration. The first incretin hormone, glucose-dependent insulinotropic polypeptide (GIP), was isolated by John Brown in the 1970s (2). Here, we describe the discovery and characterization of the second incretin hormone, GLP-1. We highlight 3 decades of science from multiple laboratories supporting the development of GLP-1- and GLP-2-based therapies. GLP-1 is now used for the treatment of type 2 diabetes (T2D) and obesity, whereas GLP-2 is used for the therapy of short bowel syndrome (SBS).

\section{Discovery of GLP-1}

Although GIP was isolated through classical peptide purification and protein sequencing methodology, the discovery of the GLP-1 sequence stemmed from the application of recombinant DNA approaches developed in the laboratories of Stanley Cohen, Paul Berg, and Herb Boyer in the early 1970s. This remarkable new technology allowed for a rapid and accurate prediction of the amino acid sequences of proteins by the decoding of the nucleotide

Conflict of interest: D.J. Drucker is supported by the Canada Research Chairs program and a BBDC-Novo Nordisk Chair in incretin biology, and has received speaking or consulting honorarium from Arisaph, Intarcia, Merck, Pfizer, and Novo Nordisk Inc. Mt. Sinai Hospital receives research support from GSK, Merck, and Novo Nordisk, for preclinical studies in the Drucker laboratory. J.J. Holst has served as a consultant or advisor to Novartis Pharmaceuticals, Novo Nordisk, Merck Sharp \& Dohme, and Roche and has received fees for lectures from Novo Nordisk, Merck Sharp \& Dohme, and GlaxoSmithKline.

Reference information: J Clin Invest. 2017;127(12):4217-4227. https://doi.org/10.1172/JCI97233

sequences of cloned recombinant cDNA copies of messenger RNAs. The Habener lab utilized this technology to elucidate proglucagon amino acid sequences from cDNAs and genes isolated from anglerfish in the early 1980s (3-5) and the rat proglucagon cDNA and gene sequences followed shortly thereafter (refs. 6, 7, Figure 1, and Figure 2). Corresponding proglucagon sequences from hamster, bovine, and human were identified by Graeme Bell and others in the early 1980s (8-10). These sequences revealed that glucagon and related GLP sequences were encoded by larger protein precursors, termed preprohormones (Figure 2). The anglerfish preproglucagons (Figure 2A), isolated and characterized by Lund and Goodman (3-5), were interesting as there were two different cDNAs encoded by separate (nonallelic) genes and they each contained a glucagonrelated sequence, in addition to glucagon. The two anglerfish glucagon-related peptides resembled GIP, a glucoincretin hormone released from the gut into the circulation during meals, subsequently shown by Dupre and Brown in 1973 to augment glucose-dependent insulin secretion (11). Unlike the two anglerfish preproglucagons, each of which harbored glucagon and a single glucagon-related peptide, the mammalian preproglucagons all contained glucagon and two additional glucagon-related peptides, designated GLP-1 and GLP-2 (Figure 2B). Notably, the corresponding amino acid sequences of the GLP-1s in the four mammalian species were identical (12), with conservation of sequence implying as yet unknown but potentially important biological actions of GLP-1.

Collectively, these findings further supported the evolving notion at the time that small peptide hormones are synthesized in the form of larger prohormones and that the final bioactive peptides are formed posttranslationally by selective enzymatic cleavages from the prohormones (Figure 2B). Earlier studies 


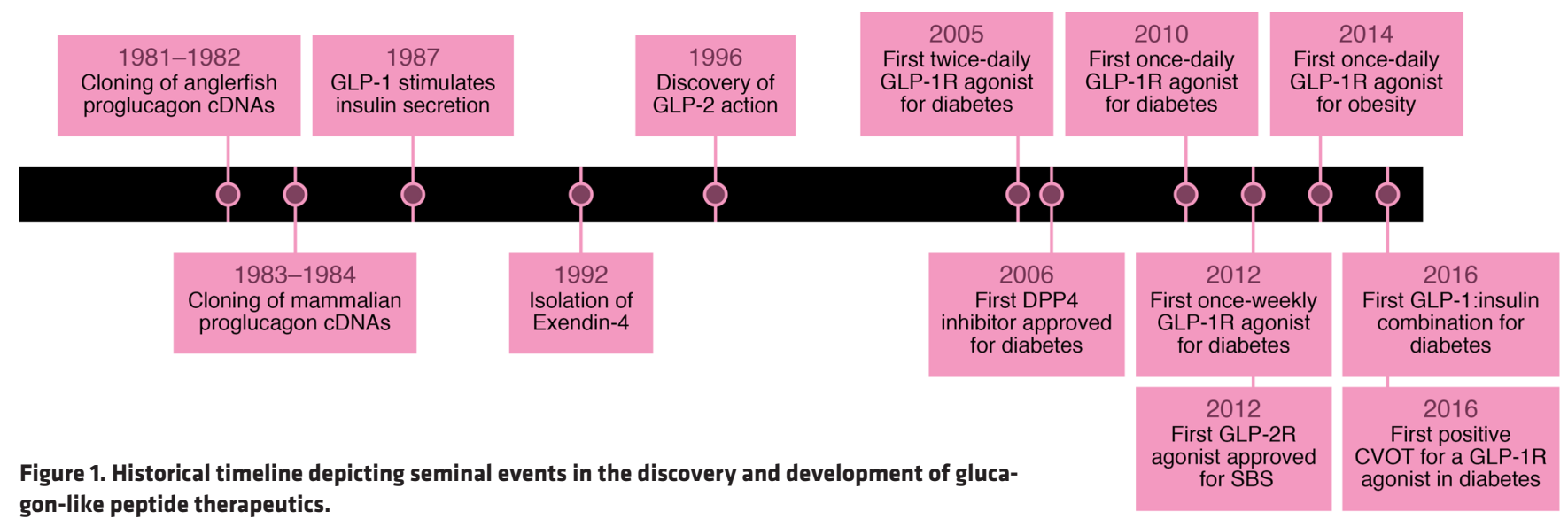

had demonstrated that insulin and parathyroid hormone are synthesized as preprohormones. The hydrophobic amino terminal sequences, termed the pre- or signal sequences, are cleaved from the nascent polypeptide chains during their translation on ribosomes, leaving the prohormones as the precursor of the peptide hormones. The $\mathrm{A}$ and $\mathrm{B}$ chains of insulin and parathyroid hormone were found to be cleaved from their respective prohormones by the actions of specific endopeptidases, prohormone convertases, which cleave proteins at the sites of two consecutive basic amino acids, arginine and lysine (13). These earlier findings of prohormone convertase specificity were applied to deduce potential cleavage sites in proglucagon.

\section{Structure-activity properties of GLP-1}

Examination of the amino acid sequence of proglucagon initially presented a conundrum regarding the processes by which potentially bioactive GLP-1 peptides might be liberated from the prohormone (Figure 2B). In keeping with the rule that bioactive peptides are cleaved from prohormones at sites consisting of two basic amino acids (13), several investigators initially predicted that bioactive GLP-1 would be a peptide of 37 amino acids beginning with histidine and ending in glycine, GLP-1(1-37). However, further inspection of the prohormone sequences revealed a second single basic amino acid followed by histidine residing 6 amino acids carboxylproximal to the first histidine, predicting a GLP-1 peptide of 31 amino acids,
GLP-1(7-37). Further, at the carboxylterminal region of the putative GLP-1 peptide resides a sequence RGRR predicting a prohormone convertase-directed cleavage site followed by an amidation of the penultimate arginine by a peptidylglycine $\alpha$-amidating monooxygenase (14) resulting in peptides of 36 and 30 amino acids, GLP-1(1-36) amide and GLP-1(7-36) amide

The availability of the amino acid sequences of GLP-1 and GLP-2 obtained from the decoding of the nucleotide sequences based on the genetic code allowed for the chemical synthesis of the predicted peptides, examination of their biological activities, and preparation of peptide-specific antisera. Daniel Drucker joined the Habener laboratory in the summer of 1984, with the original intent of studying the molecular control of thyroid hormone biosynthesis. However, the thyroid group, led by Bill Chin, was decamping for the Brigham and Women's Hospital, and Daniel was assigned to work on the proglucagon gene. To understand whether proglucagon might be processed to yield multiple proglucagon-derived peptides (PGDPs), including GLP-1 and GLP-2, Drucker transfected a proglucagon cDNA expression vector into fibroblasts, pituitary cells, and islet cells (15). Although minimal processing was observed in fibroblasts, immunoreactive GLP-1 and GLP-2 was detected by chromatography and radioimmunoassays in medium and extracts from transfected pituitary and islet cells (15). Application of similar chromatography and radioimmunoassay techniques in studies of rat (16), pig (17), and human (18) tissues revealed distinct profiles of PGDPs in pancreas and gut (Figure 3). Of note, in addition to glucagon, the pancreas contained a large peptide with immunoreactive determinants for both GLP-1 and GLP-2 (but not glucagon), consistent with incompletely cleaved proglucagon (major proglucagon fragment [MPGF]) (Figure 3, $A$ and $C$, and ref. 19). In contrast to findings in pancreas, immunoreactive GLP-1 peptides detected in gut extracts consisted entirely of smaller peptides (refs. 15 and 16 , and Figure 3, B and C). These findings indicated that the cleavage of proglucagon into small GLP-1-immunoreactive peptides was more efficient in the gut compared with pancreas. These observations were also consistent with the incretin concept in which, in response to oral nutrients, glucoincretin hormones such as GIP (and subsequently GLP-1) originate from the gut and not the pancreas.

Svetlana Mojsov in the Habener laboratory detected glycine-extended and arginine-amidated isoforms of GLP-1 - as well as both the amino-terminally extended peptides GLP-1(1-37) and GLP-1(1-36) ${ }_{\text {amide }}$ and the amino-truncated peptides GLP-1 (7-37) and GLP-1(7-36) $)_{\text {amide }}$ - in extracts of pancreas (Figure 3A). Nevertheless, the abundance of these peptides was much greater in the gut (20).

\section{Bioactivities of the GLP-1 peptides}

The earliest studies of the bioactivities of GLP-1(1-37) were indecisive. One study found that the 37 amino acid peptide activated adenylyl cyclase in membranes prepared from rat pituitary and hypothalamus (21), whereas another study failed to detect any effects of the peptide on glucose and insulin in cortisone-treated rabbits 
A

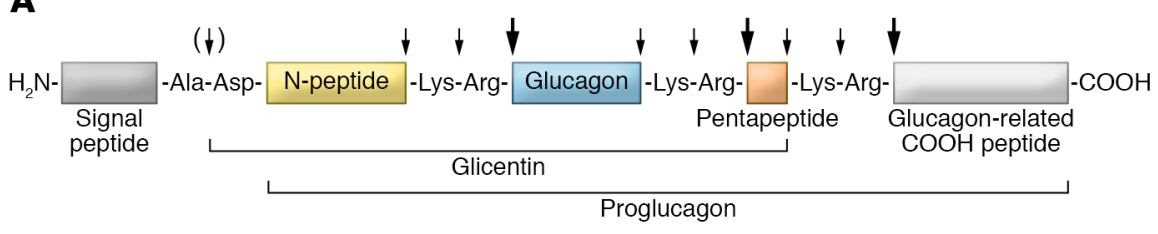

B

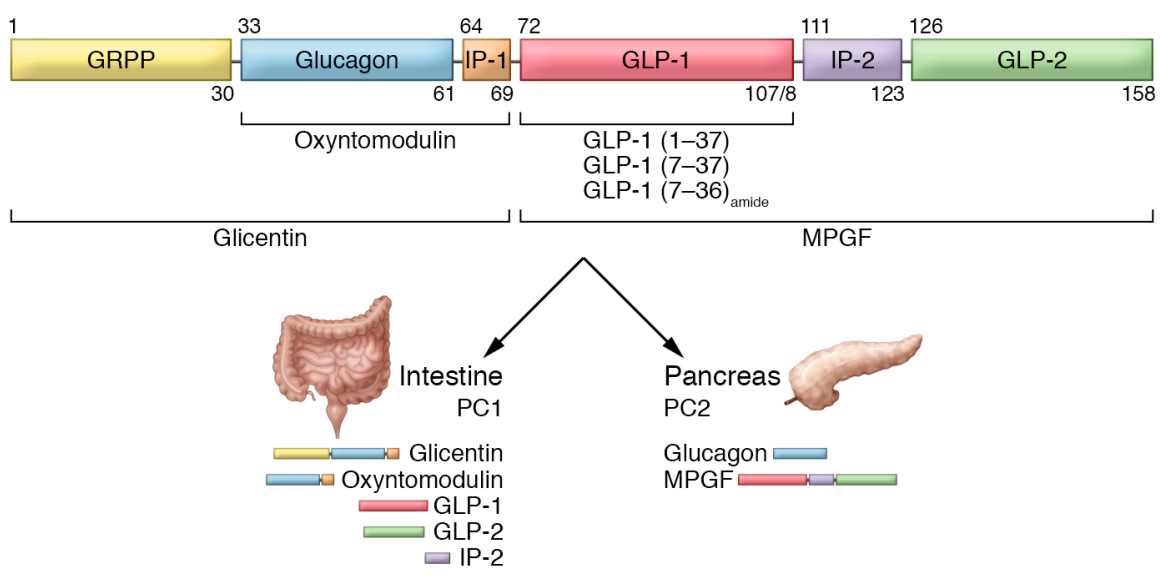

Figure 2. Structure and processing of anglerfish and human proglucagon. Representation of the structures of proglucagon cDNAs from Anglerfish (A) and Human (B), with tissue-specific liberation of individual proglucagon-derived peptides in pancreas or intestine. $P C 1$, prohormone convertase 1; PC2, prohormone convertase 2; MPGF, major proglucagon fragment. Arrows in $\mathbf{A}$ represent sites of cleave by prohormone convertase enzymes.

(22). To determine whether the shorter GLP-1 isoforms were bioactive, Drucker incubated truncated forms of GLP-1 with multiple cell lines, examining cell growth, gene expression, and signal transduction. Remarkably, insulin-producing islet cells responded to N-terminally truncated forms of GLP-1, exhibiting increased levels of cyclic AMP accumulation within minutes of exposure to $50 \mathrm{pM}-5 \mathrm{nM}$ GLP1(7-37) (Figure 4A). In contrast, neither glucagon, GLP-1(1-37), or GLP-1(1-36)NH2 increased cAMP accumulation at these concentrations (23). GLP-1(7-37) also increased the levels of insulin mRNA transcripts and stimulated insulin secretion at $25 \mathrm{mM}$ but not $5.5 \mathrm{mM}$ glucose in studies with isolated islet cell lines (Figure $4, \mathrm{~B}$ and $\mathrm{C}$, and ref. 23). In contrast, neither glucagon nor GLP-2 induced insulin gene expression. Furthermore, GLP-1 (7-37) had no effect on levels of angiotensin gene expression in the insulinoma cell line and did not change levels of glucagon, prolactin, and corticotropin mRNAs in islet or pituitary cell lines (23). Hence, these findings (Figure 4, A-C) published in 1987 (23) established that GLP-1(7-37) directly augments glucose-dependent insulin biosynthesis and secretion from $\beta$ cells.
The demonstration that GLP-1 directly increased cAMP levels provided conditional evidence for the existence of a Gs protein-coupled receptor in $\beta$ cells. In studies of insulin secretion using the isolated perfused pancreas, Mojsov and Weir demonstrated that GLP-1(7-37) and not GLP-1(1-37) stimulated insulin secretion at concentrations as low as $50 \mathrm{pM}$ (ref. 24 and Figure 5, A-C). Likewise, as outlined below, Jens Holst and colleagues showed that luminal glucose stimulated GLP-1 secretion from the perfused intestine (Figure $5 \mathrm{D}$ ), and doses from $500 \mathrm{pM}$ to $5 \mathrm{nM}$ GLP-1(7-36) ${ }_{\text {amide }}$ stimulated insulin secretion in the perfused pig pancreas (Figure $5 \mathrm{E}$ and ref. 25). Thus, it turned out that a cleavage in proglucagon at the single basic amino acid, arginine, and not the double basic amino acids, generated the active GLP-1 peptides, GLP-1(7-37) and GLP-1 $(7-36)_{\text {amide }}$ (Figure 5C). First in man studies reported in December 1987 by Kreymann and Bloom (26) rapidly established the insulinotropic actions of GLP-1(7-36) amide in human subjects. Although numerous studies have demonstrated that the aminoterminally truncated forms of GLP-1, GLP1(7-37), and GLP-1(7-36) ${ }_{\text {amide }}$ are active glucoregulatory hormones, no compelling bioactivities for the extended forms, GLP-1 (1-37) and GLP-1(1-36) ${ }_{\text {amide }}$, have yet been determined. Furthermore, no distinctive biological activities have been attributable specifically to the amidated forms of GLP-1.

\section{The view from Denmark}

In Copenhagen, Jens Holst and colleagues were interested in the incretin effect and were studying the condition of postprandial reactive hypoglycemia after gastric surgery (27). This type of hypoglycemia was clearly hyperinsulinemic, yet the signal for insulin secretion was unknown. Looking for possible candidates, they were inspired by Lise Heding's work on glucagon and her identification of the immunological differences between gut and pancreatic glucagon (28). Knowing that glucagon would stimulate insulin secretion, they were interested in the numerous cells in the gut that produce immunoreactive glucagon (29). Eventually, this work led to the identification of glicentin and oxyntomodulin (Figure 2B), which both contain the full glucagon sequence, explaining the immunoreactivity in the gut (30-32).

Having identified all of the molecular components of glicentin also in the pancreas (33), they proposed that glicentin represents at least part of a common gut and pancreatic glucagon precursor, which undergoes differential processing in the two tissues, a hypothesis subsequently confirmed through identification of the human proglucagon gene by Graeme Bell and colleagues (7). However, it was also clear that proglucagon was larger than glicentin, and the interest focused on peptides contained within the MPGF representing the remainder of proglucagon (minus glicentin) (34). The early work decoding the anglerfish proglucagon cDNA by Lund and Habener (3) followed by elucidation of the hamster proglucagon cDNA by Graeme Bell (9) supported a hypothesis that cleavage of MPGF might result in liberation of the GLPs. The Holst group quickly developed radioimmunoassays for GLP-1 and GLP-2 to test this hypothesis. To their excitement, they found that MPGF was indeed differentially processed in the gut, but not in the pancreas, to yield two GLPs (ref. 17 and Figure 3C). However, using the perfused pancreas preparation, they soon realized that neither of the two GLPs used in these 
A Pancreas

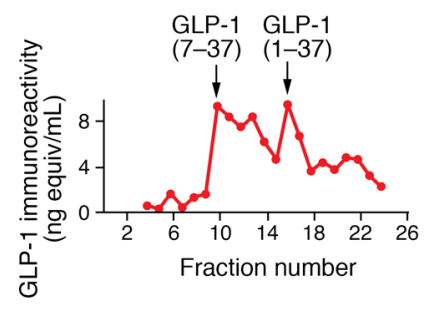

B Small intestine

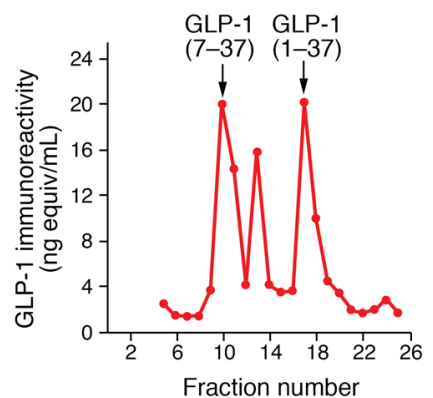

Fraction number
C
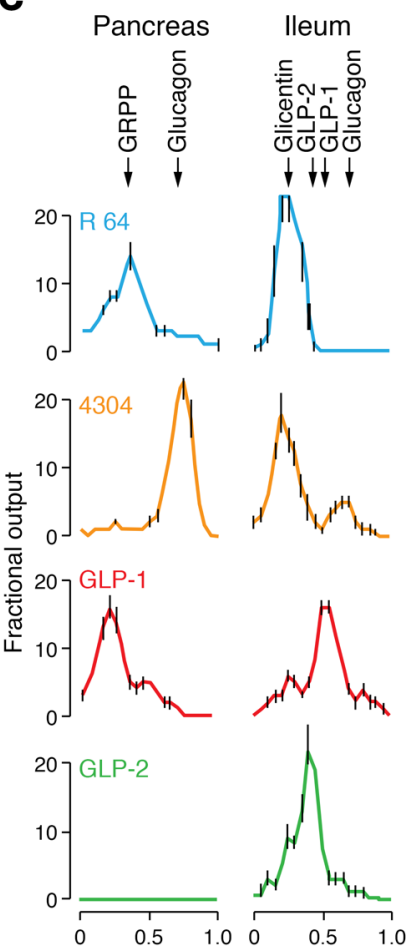

Figure 3. Processing of proglucagon and glucagon-like peptides in the pancreas and intestine. Detection of immunoreactive forms of GLP-1 in extracts from rat pancreas (A) and intestine (B) as adapted from ref. 16. Characterization of proglucagon-derived peptide immunoreactivity secreted from perfused pig pancreas and intestine $(\mathbf{C})$ using peptide-specific antisera reveal tissue-specific posttranslational processing of the PGDPs, as outlined in ref. 17.

studies had any effect on pancreatic hormone secretion. They therefore decided to isolate the naturally occurring hormone from porcine and human and gut extracts, and they found that the naturally occurring peptide was a truncated from of GLP-1 representing proglucagon (aa 78-108) (Figure 5C) and subsequently found to be amidated, corresponding to proglucagon 78-107 amide (35). Importantly, this hormone was potently insulinotropic (Figure $5 \mathrm{E}$ and ref. 25), so they had also described a new incretin hormone in 1987; however, they wondered whether GLP-1 was more interesting than the already known incretin GIP, which exhibited a diminished effect on insulin secretion in patients with T2D (36). They soon found, using the perfused pancreas, that GLP-1 - in contrast to GIPalso powerfully inhibits glucagon secretion (37). Eventually, they demonstrated that during infusions of physiological amounts of GLP-1 into humans, insulin secretion would be stimulated and glucagon secretion inhibited, resulting in a decrease in hepatic glucose production (38). However, the effect was self-limiting, with the insulin- stimulating activity attenuated as plasma glucose levels started to fall, limiting the fall to $0.5-1 \mathrm{mmol} / \mathrm{l}$.

At that time, the Copenhagen group realized that GLP-1 was extremely interesting and, in further studies, demonstrated that it strongly inhibited gastric motility and gastric and pancreatic exocrine secretion (39), consistent with an important role for this hormone as a regulator of upper gastrointestinal function. They also demonstrated that infusions of GLP-1 in humans inhibited appetite and food intake, actions subsequently exploited in the clinic to treat obesity (40). In studies published in 1993 by Michael Nauck and colleagues in Göttingen, i.v. infusion of GLP-1 completely normalized severely elevated fasting glucose concentrations in patients with long-standing T2D as a consequence of the actions of GLP-1 to stimulate insulin and inhibit glucagon secretion (41). Although GLP-1 clearly had therapeutic potential, s.c. injections of GLP-1 were disappointingly ineffective (42). The explanation was an extremely rapid metabolism and inactivation of GLP-1. With inspiration from Rolf
Mentlein in Kiel, Holst and Deacon showed that the GLP-1 molecule was cleaved by the enzyme dipeptidyl-peptidase-4(DPP-4) in vivo and that inhibitors of this enzyme could completely protect the molecule (43). In fact, the circulating half-life of GLP-1 was only 1.5-2 minutes in human subjects with diabetes, and they proposed that inhibitors of DPP-4 could maintain higher levels of intact active endogenous GLP-1 for therapeutic purposes (44). Subsequent studies soon demonstrated that DPP-4-resistant GLP-1 analogues were longer-acting than native GLP-1 (45). Furthermore, inhibitors of DPP- 4 completely prevented the breakdown of GLP-1 in the circulation and amplified the insulinotropic actions of GLP-1 (46). This exciting development, presented in a Perspectives article in Diabetes in 1998 (47), was soon followed by the development of clinically useful inhibitors, first vildagliptin and subsequently sitagliptin.

It remained to be understood whether GLP-1 receptor agonists would actually be useful for clinical diabetes therapy or whether tachyphylaxis would develop upon chronic administration. The group in Copenhagen administered synthetic GLP-1 by constant s.c. infusion for 6 weeks to a group of individuals with long-standing T2D (48). Fortunately, no tachyphylaxis was observed; GLP-1 therapy reduced fasting and mean plasma glucose by 4.3 and $5.5 \mathrm{mmol} / \mathrm{l}$; glycated hemoglobin by $1.3 \%$; and body weight by $2 \mathrm{~kg}$. Moreover, insulin sensitivity and $\beta$ cell function, assessed by clamp studies, greatly improved. Importantly, no limiting side effects were recorded (48), providing proof of concept in 2002 for GLP-1 therapy in subjects with T2D. It was now clear that GLP-1-based therapies had tremendous potential.

\section{The Toronto perspective: the physiology of GLPs and discovery of GLP-2}

Building on the availability of cloned proglucagon gene sequences in the Habener lab (6), Daniel Drucker and Jacques Philippe pursued the analysis of the molecular control of islet $\alpha$ cell proglucagon gene expression in the mid 1980s $(49,50)$. Upon returning to Toronto in 1987, Drucker extended these studies to examine proglucagon gene expression in the intestine 
A

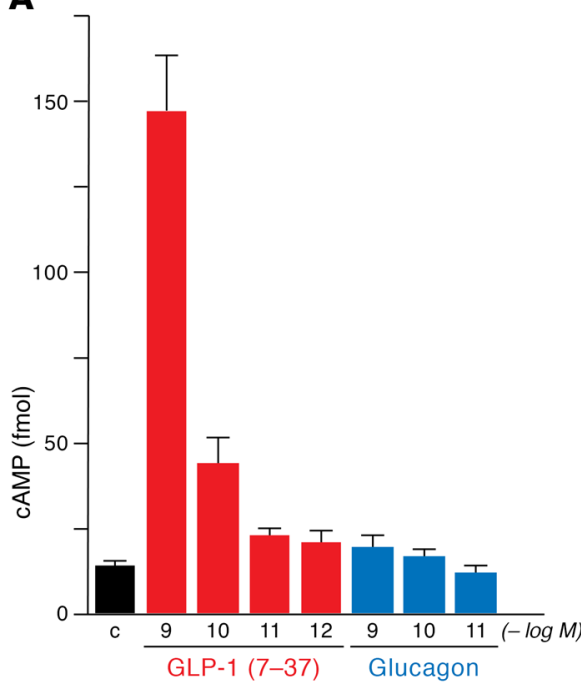

B

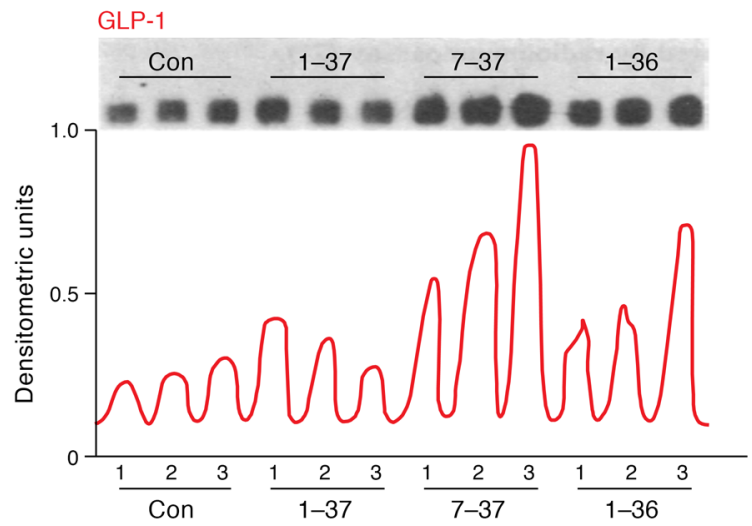

C

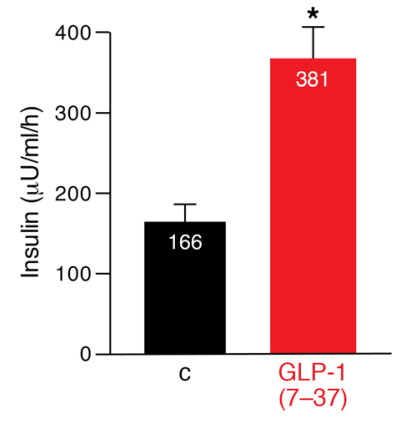

Figure 4. GLP-1 directly stimulates signal transduction and glucose-dependent insulin secretion in islet cells. GLP-1(7-37) directly stimulates cyclic AMP accumulation (A), insulin gene expression (B), and glucose-dependent insulin secretion (C) in a rat insulinoma cell line, as adapted from ref. 23.

and CNS. He isolated human neonatal brainstem cDNAs encoding proglucagon, which exhibited an identical sequence to that described for islet proglucagon (51). Molecular cloning of the rat intestinal proglucagon cDNA similarly revealed an open reading frame identical to that elucidated for the rat pancreatic islet proglucagon cDNA (52). Moreover, in studies carried out in collaboration with Patricia Brubaker, forskolin, cholera toxin, and dibutyryl cyclic AMP increased the synthesis and secretion of intestinal PGDPs from primary cultures of rat intestinal cells (52). At the time, there were no differentiated GLP-1secreting enteroendocrine cell lines suitable for studies of intestinal proglucagon gene expression. Accordingly, Ying Lee, a fellow in the Drucker laboratory, generated a transgenic mouse expressing the SV40 T antigen cDNA under the control of the proglucagon gene promoter. This transgenic mouse reproducibly developed GLP-1secreting enteroendocrine tumors of the colon (53), enabling isolation of the first differentiated GLP-1-producing enteroendocrine L cell line in 1992, designated GLUTag cells. GLUTag cells were easily propagated ex vivo; secreted immunoreactive GLP-1, glicentin, oxyntomodulin, and GLP-2 in response to cyclic AMP analogues $(54,55)$; and resembled primary cultures of nonimmortalized gut endocrine cells in regard to their response to a battery of secretagogues (56).
Two unexpected observations were made during isolation of GLUTag cells. First, mice harboring s.c. GLUTag cell tumors exhibited a marked reduction of pancreatic islet $\alpha$ cell mass (57). Second, mice with s.c. GLUTag, InR1-G9, or RIN1056A glucagon-producing tumors all exhibited marked enlargement of the small bowel. These findings led Drucker to reinvestigate the link between glucagonproducing tumors and gut growth, first reported in a human subject studied at the Hammersmith hospital in 1970 by Dowling and colleagues in London (58). A series of simple experiments from the Drucker lab published in 1996 identified GLP-2 as the PGDP with the most potent intestinotrophic activity in mice (58). Remarkably, although immunoreactive GLP-2 had been detected in intestinal extracts of various species (refs. 16, 59, and Figure 3), no previous biological activity had yet been identified for GLP-2 in vivo.

The actions of GLP-2 to stimulate small bowel growth were rapid, detectable within days, and associated with increased crypt cell proliferation (58). Surprisingly, when similar doses of GLP-2 were administered to rats, intestinal growth was not significantly increased, although an increase in crypt plus villus height was observed (60). With hindsight, these findings reflected the importance of DPP- 4 for the degradation of GLP-2, more evident in rats than in mice. Subsequent studies in the Drucker lab demonstrated that native GLP-2 robustly increased small bowel growth in Fischer 344 rats with an inactivating mutation in the Dpp4 gene (60). Furthermore, a GLP-2 analogue with a single amino acid substitution [Gly2]-GLP-2 exhibited substantial resistance to DPP-4 cleavage and robust intestinotrophic activity in normal rats in vivo (60). Hence, the importance of DPP4 for cleavage of both GLP-1 and GLP-2 became evident very early in the study of the GLPs.

The identification of GLP-2 as an intestinal growth factor spurred a series of experiments examining the actions of GLP-2 in the context of experimental gut injury. GLP-2 administration was generally associated with preservation of gut mucosal structure and function in the setting of chemical, radiation, or surgically induced intestinal injury in preclinical studies (61-63). Notably, GLP-2 also rapidly increased nutrient absorption in normal rodents (64) and in animals with surgical gut resection mimicking SBS (65). Excitingly, the findings in animals were soon extended to humans with SBS. In a pilot study carried out around 2000-2001, Jeppesen and colleagues demonstrated that native GLP-2 administered twice daily for 35 days increased nutrient absorption, energy absorption, and weight gain in human subjects with SBS (66). These findings, namely expansion of intestinal mucosal surface area coupled with 
A GLP-1 (7-37)

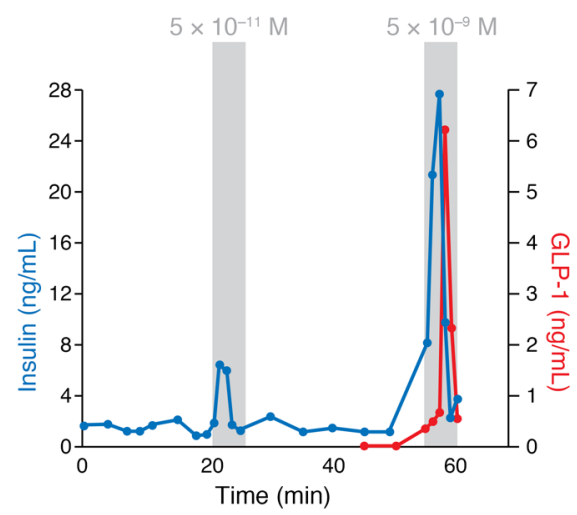

B GLP-1 (1-37)

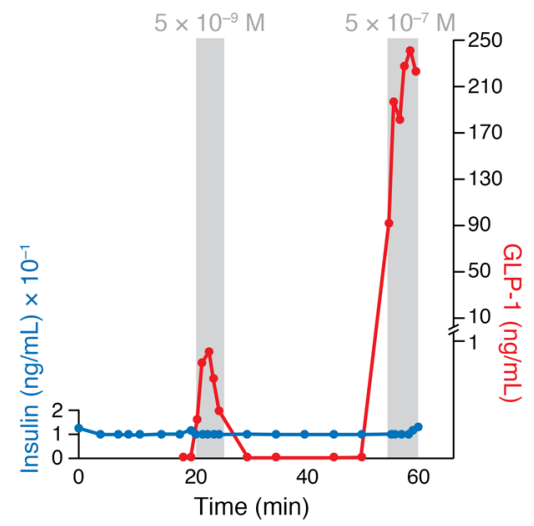

\section{C}

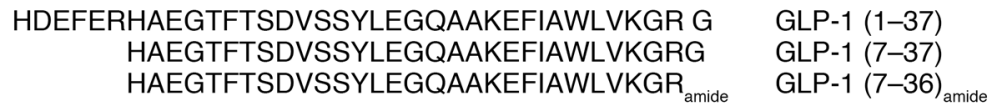

D
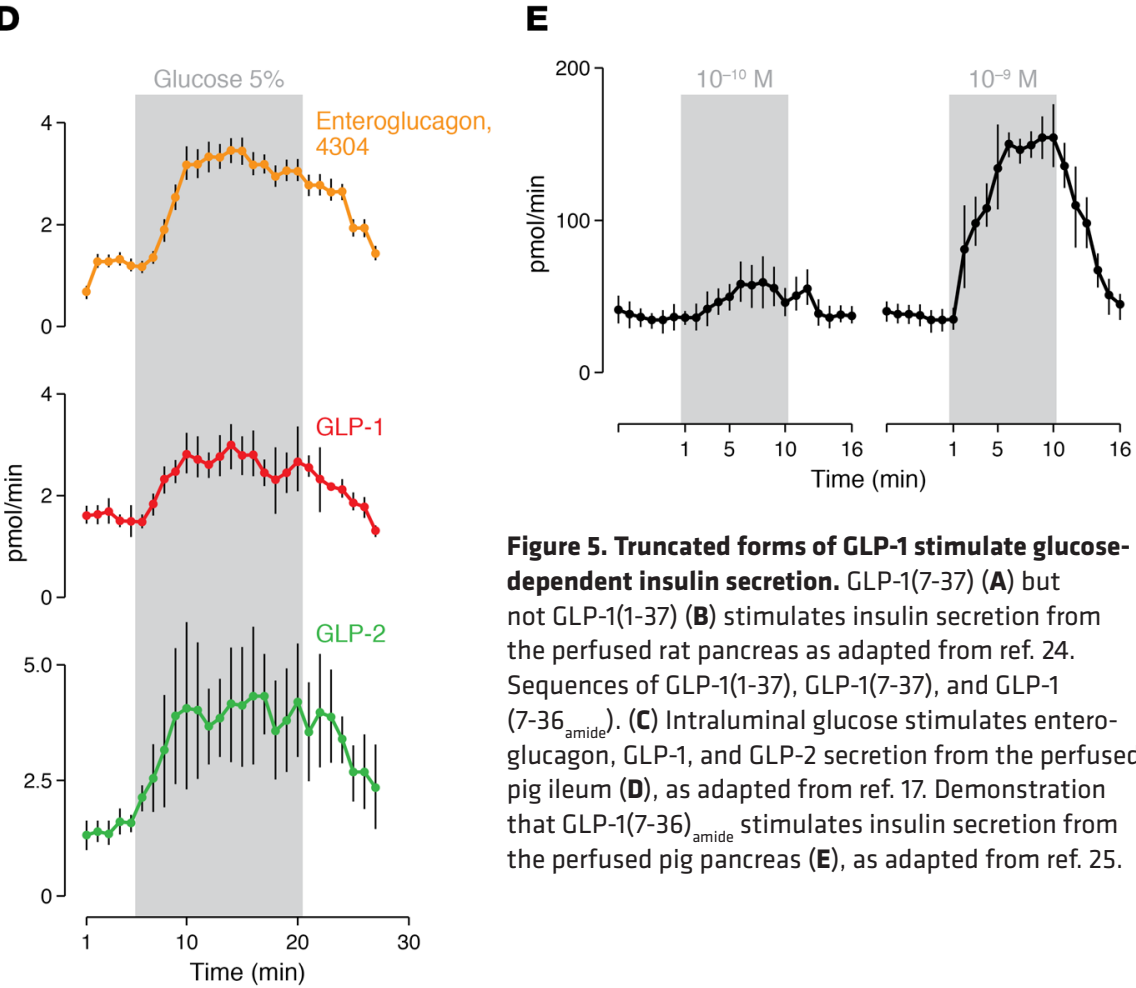

Figure 5. Truncated forms of GLP-1 stimulate glucosedependent insulin secretion. GLP-1(7-37) (A) but not GLP-1(1-37) (B) stimulates insulin secretion from the perfused rat pancreas as adapted from ref. 24 Sequences of GLP-1(1-37), GLP-1(7-37), and GLP-1 $\left(7-36_{\text {amide }}\right)$. (C) Intraluminal glucose stimulates enteroglucagon, GLP-1, and GLP-2 secretion from the perfused pig ileum (D), as adapted from ref. 17. Demonstration that GLP-1(7-36) $)_{\text {amide }}$ stimulates insulin secretion from the perfused pig pancreas (E), as adapted from ref. 25.

enhanced nutrient absorption (67), together with substantial preclinical data, supported the initiation of a drug development program to test the efficacy of GLP-2 in human subjects with parenteral nutritiondependent (PN-dependent) SBS. Clinical studies were initiated with h[Gly2]-GLP-2, a degradation-resistant GLP-2 analogue discovered in the Drucker lab (60) and subsequently designated teduglutide. Once daily teduglutide administration in human subjects with PN-dependent SBS resulted in increased fluid and energy absorption, while reducing the requirements for $\mathrm{PN}$, in two separate placebo-controlled Phase 3 studies $(67,68)$. Teduglutide was approved for chronic therapy of subjects with PN-dependent SBS in the US in December 2012 (67).

\section{The physiology of GLP-1 action}

Complementary studies in the Drucker lab were focused on defining the physiological importance of endogenous GLP-1 through generation of Glp1r ${ }^{-/}$mice. These animals generated by Louise Scrocchi exhibited impaired oral glucose tolerance and reduced insulin levels after glucose stimulation, demonstrating the critical role of endogenous GLP-1 as an incretin hormone in 1996 (69). Unexpectedly, Glp1r ${ }^{-/}$mice also exhibited fasting hyperglycemia, and impaired i.p. glucose tolerance, establishing the importance of the GLP- 1 for $\beta$ cell function beyond its original description as an incretin. Moreover, GLP-1R-deficient $\beta$ cells exhibit enhanced sensitivity to apoptotic injury, whereas pharmacological activation of GLP-1R signaling attenuated $\beta$ cell death in mice in vivo, as well as in cultures of purified rat $\beta$ cells studied ex vivo (70). The importance of GLP-1R signaling for the response to cellular stress was highlighted by findings that activation of GLP$1 \mathrm{R}$ signaling attenuated the development of ER stress in $\beta$ cells by enhancing ATF- 4 induction and accelerating recovery from translational repression via augmentation of ER stress-stimulated ATF-4 translation (71). Collectively, these findings explain how GLP-1, despite acting to simultaneously enhance insulin biosynthesis and secretion, maintains functional $\beta$ cell mass through attenuation of ER stress.

The actions of GLP-1 to stimulate insulin and inhibit glucagon secretion, together with its inhibitory effects on food intake and gastric emptying, spurred considerable effort in development of GLP-1-based therapeutics. Remarkably, the first GLP-1R agonist approved for clinical use was exenatide (synthetic exendin-4), a peptide originally isolated from Heloderma suspectum lizard venom by John Eng in 1992 (72). Subsequent molecular cloning studies published by the Drucker laboratory in 1997 demonstrated that the lizard genome contains two distinct proglucagon gene sequences encoding GLP-1 and a separate proexendin gene, largely restricted in its expression to the salivary gland (73). The original clinical development program for exendin-4 utilized twice-daily injections of the unmodified peptide. Pivotal studies in subjects with T2D ultimately resulted in the approval of twice-daily exenatide, the first GLP-1R agonist in 2005 (Figure 1). These efforts spurred the development of a once-weekly form of exenatide in a microsphere suspension, ultimately the first once-weekly therapy approved for diabetes in 2012 (Figure 
1). Exenatide once weekly was more effective than the twice-daily preparation, with greater reduction of glycemia and comparable control of body weight (74). Today, multiple GLP-1R agonists (small peptides and high molecular weight proteins) are approved for the treatment of $\mathrm{T} 2 \mathrm{D}$, and a single drug, liraglutide, was approved for the treatment of obesity in 2014 (Figure 1).

The widespread distribution of GLP-1 receptors in extrapancreatic tissues stimulated considerable research into the nonglycemic actions of GLP-1. Indeed, we now understand that GLP-1 controls inflammation (75), reduces experimental kidney injury (76), and like GLP-2, acts as a potent intestinal growth factor through mechanisms including stimulation of crypt fission (ref. 77 and Figure 6). Among the actions of GLP-1 that have engendered the most interest are its effects in the cardiovascular system. Native GLP-1 increases flow-mediated vasodilation, enhances heart rate (HR) and cardiac output, and is cardioprotective in preclinical studies, most notably in animals with ischemic cardiac injury (78). Although degradationresistant GLP-1R agonists have minimal effects on blood vessels (79), they increase $\mathrm{HR}$ and reduce cardiac inflammation and infarct size in animals with experimental myocardial infarction $(75,80)$. Understanding the mechanisms through which GLP-1 exerts cardioprotection is challenging, since the GLP-1R is largely expressed in atrial and not ventricular cardiomyocytes (81). Furthermore, the GLP$1 \mathrm{R}$-dependent control of inflammation in heart and blood vessels is complex, as the predominant site of GLP-1R expression in the (murine) immune system is within the intestinal intraepithelial lymphocyte (82).

Several cardiovascular outcome studies have documented the safety of GLP-1R agonists in human subjects with T2D and preexisting cardiovascular disease $(83,84)$. Excitingly, reduction of major adverse cardiovascular events was reported in human subjects treated with long-acting liraglutide and semaglutide $(85,86)$. These findings, revealed more than a decade after the first approval of twice-daily exenatide in 2005 , have rekindled enthusiasm for the use of GLP-1R agonists, alone or in combination, in the treatment of $\mathrm{T} 2 \mathrm{D}$ and obesity, most compellingly in subjects at high risk for cardiovascular disease. Today, only two drug classes used for treatment of T2D, the GLP$1 \mathrm{R}$ agonists and SGLT- 2 inhibitors, produce weight loss, effective reduction of A1c, a low incidence of hypoglycemia, and reductions in rates of major adverse cardiovascular events and cardiovascular death $(75,87)$.

\section{Challenges in studies of GLP-1 and in development of GLP-1R agonists}

In the era of rapid daily progress in biomedical science, it is surprising that it took almost 20 years from identification of GLP-1 to successful approval of the world's first clinically utilized GLP-1R agonist. The rapid renal clearance of many small peptides like GLP-1, together with its inactivation by DPP4, required development of longer-acting peptides with greater stability and enhanced resistance to DPP-4. The development of nausea and vomiting, encountered in every GLP-1 development program, often limited dose escalation and likely delayed introduction of GLP-1R agonists, utilized at higher doses, with greater efficacy. Indeed, it has now become apparent that rates of nausea and vomiting can be greatly reduced with much slower titration regimens, as has been the case in development of titratable GLP-1-insulin combination therapies. Indeed, the development of liraglutide for obesity using a 3-mg daily dosing regimen further illustrates that much greater tolerability to GLP-1 can be achieved using progressive stepwise titration regimens.

Studies of GLP-1 synthesis, secretion, and action have also been hampered by lack of suitable reagents and experimental challenges. Circulating GLP-1 levels are very low, and measurement of GLP-1 in the circulation is technically challenging; indeed, not all commercial assays produce consistent or accurate results, and many exhibit problematic sensitivity and specificity (88). Similar challenges surround the quantitative detection of GLP-2 (89), which is challenging to measure with available commercial assays. Complementary problems have been identified with the antisera used to detect the GLP-1 and GLP-2 receptors, with problematic antisera utilized in dozens of publications. The majority of commercially available antisera used to detect GLP-1R and GLP2R exhibit impaired sensitivity and specificity $(67,90)$, challenging published con- clusions surrounding receptor expression and localization.

Elucidation of the physiological roles of endogenous GLP-1 and GLP-2 in humans has been limited in part due to limitations associated with the available antagonists. Exendin(9-39) has been widely used as a GLP-1 receptor antagonist, yet only in short-term human studies. It seems likely that more selective antagonists with optimized pharmacokinetic profiles would advance our understanding of the importance of endogenous GLP-1 action. Similarly, GLP-2(3-33), often employed as a GLP-2 receptor antagonist, is both a weak antagonist and a partial agonist, and little data is available to date that illuminates the physiological importance of endogenous GLP-2 in human subjects.

Analysis of proglucagon synthesis and secretion in rare enteroendocrine $\mathrm{L}$ cell populations in the small and large bowel is also technically challenging. Transgenic technologies have enabled isolation of primary L cell populations suitable for secretion and electrophysiological analyses (91), and stem cell-derived gut organoids, including those of human origin, herald considerable potential for generation of diverse enteroendocrine cell populations from different sites along the gastrointestinal tract (92). Remarkably, despite the theoretical potential of enhancing $L$ cell secretion for the treatment of metabolic disorders (1), there has been scant progress in clinical development of GLP-1 secretagogues exhibiting sustained efficacy in both preclinical and clinical studies.

\section{GLPs: current use and future considerations}

What does the second decade of GLP-1based therapies portend? Currently, multiple GLP-1R agonists are indicated for the treatment of T2D, and liraglutide is also approved for obesity; however, indications such as nonalcoholic steatohepatitis, Parkinson's disease, and Alzheimer's disease are being explored. Indeed, several randomized controlled clinical trials have demonstrated significant clinical improvement in human subjects with Parkinson's disease (93). Despite the appeal of current GLP-1R agonists for the treatment of T2D, market penetration for many GLP-1R agonists remains disappointing, raising questions about the potential clinical 


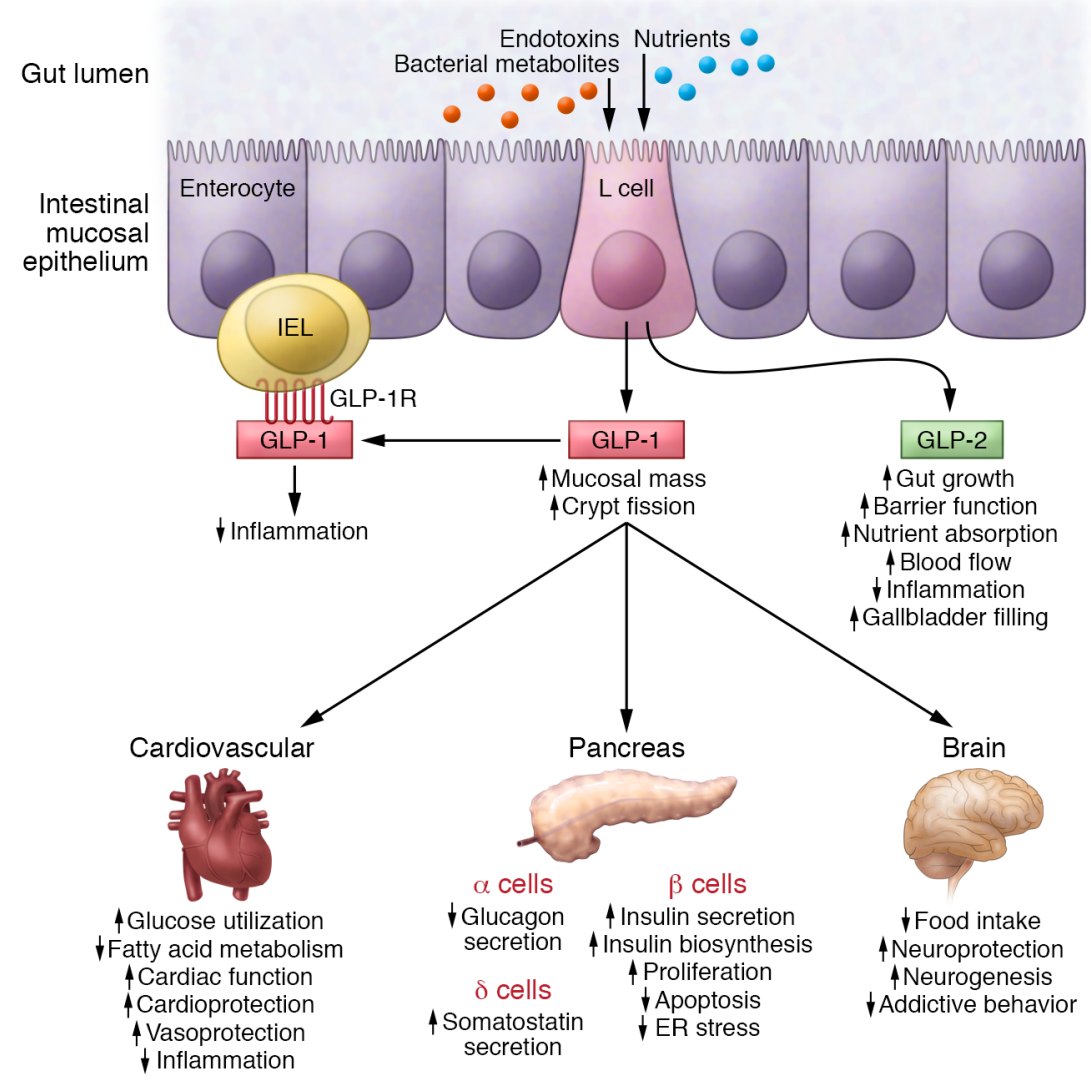

Figure 6. The pleiotropic local and systemic actions of GLP-1 and GLP-2 secreted in response to nutrients, bacterial metabolites, or inflammatory toxins and cytokines, from enteroendocrine $L$ cells of the small and large intestine.

appeal, expense, and commercial success of newer formulations. Ongoing attempts to improve the therapeutic efficacy of GLP$1 \mathrm{R}$ agonists, exemplified by once-weekly semaglutide for diabetes or once-daily semaglutide for obesity, are under active investigation. ITCA-650 is a long-acting version of exenatide enabling sustained peptide delivery with implantation of a small s.c. osmotic minipump every 3-6 months. Semaglutide is also being studied as a once-daily oral formulation (94), potentially extending the appeal of GLP$1 \mathrm{R}$ agonists to a subset of patients that may traditionally eschew injectable therapies.

Considerable effort is being expended to combine the established efficacy of GLP-1R agonism with additional therapies, enabling greater therapeutic efficacy delivered through a single injection. Two insulin-GLP-1 combination therapies have been approved, lixisenatide-insulin glargine and liraglutide-insulin degludec, enabling enhanced control of glucose without weight gain. These fixed-ratio combination therapies represent attractive options for some patients; however, the current expense of and unfamiliarity with these new drugs may limit their appeal in some markets. Whether longer-acting versions, perhaps weekly insulin-GLP-1 combinations, are feasible and efficacious requires additional investigation. Moreover, GLP-1 may yet emerge as an ideal partner for peptide combinations that enable greater weight loss. Unimolecular coagonists and triagonists exhibit substantial preclinical efficacy (95) and are under active clinical investigation. Nevertheless, it may be challenging to predict the ideal ratio(s) of 2-3 peptide epitopes combined in a single therapy that produces enhanced control of metabolic disease, while maintaining an acceptable safety profile (96).

The observations that GLP-1R signaling in $\beta$ cells is essential for control of insulin secretion, together with data suggesting that exendin(9-39) may attenuate insulin secretion through reduction of $\beta$ cell cyclic AMP (97), has supported investigational use of exendin(9-39) for the treatment of severe hyperinsulinemic hypoglycemia. Preliminary short-term data supports the feasibility of using exendin(9-39) in the therapy of bariatric surgery-associated hypoglycemia (98). Whether exendin(9-39) will exhibit sustained efficacy and safety and be similarly useful for treatment of genetic forms of hyperinsulinemic hypoglycemia requires further study. The elevated levels of GLP-1 detected in most subjects after bariatric surgery are widely viewed as contributing to the enhanced $\beta$ cell function and reduced appetite evident in these subjects (99). Nevertheless, insulin sensitivity is also rapidly improved after bariatric surgery, and some studies suggest that GLP-1 (9-36) and its degradation products, which circulate at elevated levels after bariatric surgery, may enhance insulin sensitivity in peripheral tissues. Further research into the potential contribution of these PGDPs in the context of bariatric surgery may illuminate the role(s) of these peptides in this unique clinical context.

The cardiovascular safety and benefits (Figure 6) associated with the use of GLP$1 \mathrm{R}$ agonists (75) raises further clinically relevant questions. Might nondiabetic subjects with obesity expect comparable cardioprotection with sustained GLP-1R agonism? Alternatively, can we identify the cardioprotective mechanisms of GLP-1 action and extend the therapeutic possibilities of GLP-1 therapy to nondiabetic subjects at high risk for cardiovascular disease? Similarly, will human subjects with prediabetes, or those at low risk for cardiovascular disease, be suitable candidates for GLP-1R agonism without long-term data establishing durability and reduction of complications? Additional clinical trials will be required to answer these questions.

The translational success of GLP-1 from bench to bedside reflects important contributions from dozens of colleagues studying GLP-1 over 3 decades, to whom we extend our thanks and appreciation. The history of GLP-1 science provides instructive lessons relevant to modern-day experimentation and drug development. First, the field was built slowly with a series of nonflashy yet solid studies examining the physiology, pharmacology, and pleiotropic actions of native GLP-1 and multiple GLP-1R agonists. From the onset, the availability of the native peptide enabled rapid proof of concept in human subjects, quickly validating discoveries made in preclinical studies. Most of the early, and the majority of subsequent, GLP-1 studies were published in tradition- 
al physiology or endocrinology subspecialty journals and might be described as "descriptive" or "incremental" by many colleagues. The elusive distribution of GLP-1 receptors, often expressed in small numbers of endocrine cells, CNS or enteric neurons, or rare immune cells, makes it challenging to decisively identify cells, pathways, and reductionist mechanisms linking receptor engagement to physiological actions and therapeutic efficacy. Nevertheless, the multiple actions of GLP-1, described in dozens of laboratories, have largely been reproducible, and occasional questionable findings and controversies have been extensively studied and subsequently discarded by more careful investigation (100). Taken together, the story of the discovery and characterization of the GLPs highlights how old-fashioned biochemistry, physiology, molecular biology, and traditional analyses of hormone action provides a firm scientific foundation for the development of multiple novel therapeutics for the treatment of obesity, diabetes, and intestinal disorders.

\section{Acknowledgments}

The authors thank the members of their laboratories and the hundreds of collaborative colleagues who have made key contributions to our collective understanding of glucagon-like peptide biology.

Address correspondence to: Daniel J. Drucker, LTRI, Mt. Sinai Hospital, 600 University Ave., Mailbox 39, TCP5-1004, Toronto, Ontario, Canada M5G 1X5. Phone: 416.361.2661; Email: drucker@ lunenfeld.ca.

1. Drucker DJ. Evolving concepts and translational relevance of enteroendocrine cell biology. J Clin Endocrinol Metab. 2016;101(3):778-786.

2. Brown JC, Dryburgh JR. A gastric inhibitory polypeptide. Can J Biochem. 1971;49(8):867-872.

3. Lund PK, Goodman RH, Dee PC, HabenerJF. Pancreatic preproglucagon cDNA contains two glucagon-related coding sequences arranged in tandem. Proc Natl Acad Sci U S A. 1982;79(2):345-349.

4. Lund PK, Goodman RH, Habener JF. Pancreatic pre-proglucagons are encoded by two separate mRNAs. J Biol Chem. 1981;256(13):6515-6518.

5. Lund PK, Goodman RH, Montminy MR, Dee PC, Habener JF. Anglerfish islet pre-proglucagon II. Nucleotide and corresponding amino acid sequence of the cDNA. J Biol Chem. 1983;258(5):3280-3284.

6. Heinrich G, Gros P, Habener JF. Glucagon gene sequence. Four of six exons encode separate functional domains of rat pre-proglucagon. J Biol Chem. 1984;259(22):14082-14087.

7. Heinrich G, Gros P, Lund PK, Bentley RC, Habener JF. Pre-proglucagon messenger ribonucleic acid: nucleotide and encoded amino acid sequences of the rat pancreatic complementary deoxyribonucleic acid. Endocrinology. 1984;115(6):2176-2181.

8. Bell GI, Sanchez-Pescador R, Laybourn PJ, Najarian RC. Exon duplication and divergence in the human preproglucagon gene. Nature. 1983;304(5924):368-371.

9. Bell GI, Santerre RF, Mullenbach GT. Hamster preproglucagon contains the sequence of glucagon and two related peptides. Nature. 1983;302(5910):716-718.

10. Lopez LC, Frazier ML, Su CJ, Kumar A, Saunders GF. Mammalian pancreatic preproglucagon contains three glucagon-related peptides. Proc Natl Acad Sci U S A. 1983;80(18):5485-5489.

11. Dupre J, Ross SA, Watson D, Brown JC. Stimulation of insulin secretion by gastric inhibitory polypeptide in man. JClin Endocrinol Metab. 1973;37(5):826-828.

12. Kieffer TJ, Habener JF. The glucagon-like peptides. Endocr Rev. 1999;20(6):876-913.

13. Steiner DF. The proprotein convertases. Curr Opin Chem Biol. 1998;2(1):31-39.

14. Kumar D, Mains RE, Eipper BA. 60 YEARS OF POMC: From POMC and $\alpha-M S H$ to PAM, molecular oxygen, copper, and vitamin C. J Mol Endocrinol. 2016;56(4):T63-T76.

15. Drucker DJ, Mojsov S, Habener JF. Cell-specific post-translational processing of preproglucagon expressed from a metallothionein-glucagon fusion gene. J Biol Chem. 1986;261(21):9637-9643.

16. Mojsov S, Heinrich G, Wilson IB, Ravazzola M, Orci L, Habener JF. Preproglucagon gene expression in pancreas and intestine diversifies at the level of post-translational processing. J Biol Chem. 1986;261(25):11880-11889.

17. Orskov C, Holst JJ, Knuhtsen S, Baldissera FG, Poulsen SS, Nielsen OV. Glucagon-like peptides GLP-1 and GLP-2, predicted products of the glucagon gene, are secreted separately from pig small intestine but not pancreas. Endocrinology. 1986;119(4):1467-1475.

18. Orskov C, Holst JJ, Poulsen SS, Kirkegaard P. Pancreatic and intestinal processing of proglucagon in man. Diabetologia. 1987;30(11):874-881.

19. Patzelt C, Schiltz E. Conversion of proglucagon in pancreatic alpha cells: the major endproducts are glucagon and a single peptide, the major proglucagon fragment, that contains two glucagon-like sequences. Proc Natl Acad Sci US A. 1984;81(16):5007-5011.

20. Mojsov S, Kopczynski MG, Habener JF. Both amidated and nonamidated forms of glucagon-like peptide I are synthesized in the rat intestine and the pancreas. J Biol Chem. 1990;265(14):8001-8008.

21. Hoosein NM, Gurd RS. Human glucagon-like peptides 1 and 2 activate rat brain adenylate cyclase. FEBS Lett. 1984;178(1):83-86.

22. Ghiglione M, Uttenthal LO, George SK, Bloom SR. How glucagon-like is glucagon-like peptide-1? Diabetologia. 1984;27(6):599-600.
23. Drucker DJ, Philippe J, Mojsov S, Chick WL, Habener JF. Glucagon-like peptide I stimulates insulin gene expression and increases cyclic AMP levels in a rat islet cell line. Proc Natl Acad Sci U S A. 1987;84(10):3434-3438.

24. Mojsov S, Weir GC, Habener JF. Insulinotropin: glucagon-like peptide I (7-37) co-encoded in the glucagon gene is a potent stimulator of insulin release in the perfused rat pancreas. JClin Invest. 1987;79(2):616-619.

25. Holst JJ, Orskov C, Nielsen OV, Schwartz TW. Truncated glucagon-like peptide I, an insulin-releasing hormone from the distal gut. FEBS Lett. 1987;211(2):169-174.

26. Kreymann B, Williams G, Ghatei MA, Bloom SR. Glucagon-like peptide-1 7-36: a physiological incretin in man. Lancet. 1987;2(8571):1300-1304.

27. Holst JJ, Hending LG, Rehfeld JF. Gut glucagon and reactive hypoglycaemia. Lancet. 1973;1(7810):1008.

28. Heding LG. Radioimmunological determination of pancreatic and gut glucagon in plasma. Diabetologia. 1971;7(1):10-19.

29. Holst JJ. Extrapancreatic glucagons. Digestion. 1978;17(2):168-190.

30. Holst JJ. Gut glucagon, enteroglucagon, gut glucagonlike immunoreactivity, glicentin - current status. Gastroenterology. 1983;84(6):1602-1613.

31. Holst JJ. Evidence that glicentin contains the entire sequence of glucagon. Biochem J. 1980;187(2):337-343.

32. Holst JJ. Evidence that enteroglucagon (II) is identical with the C-terminal sequence (residues 33-69) of glicentin. Biochem J. 1982;207(3):381-388.

33. Moody AJ, Holst JJ, Thim L, Jensen SL. Relationship of glicentin to proglucagon and glucagon in the porcine pancreas. Nature. 1981;289(5797):514-516.

34. Patzelt C, Schug G. The major proglucagon fragment: an abundant islet protein and secretory product. FEBS Lett. 1981;129(1):127-130.

35. Orskov C, Bersani M, Johnsen AH, Højrup P, Holst JJ. Complete sequences of glucagon-like peptide-1 from human and pig small intestine. J Biol Chem. 1989;264(22):12826-12829.

36. Krarup T, Saurbrey N, Moody AJ, Kühl C, Madsbad S. Effect of porcine gastric inhibitory polypeptide on beta-cell function in type I and type II diabetes mellitus. Metab Clin Exp. 1987;36(7):677-682.

37. Orskov C, Holst JJ, Nielsen OV. Effect of truncated glucagon-like peptide-1 [proglucagon-(78-107) amide] on endocrine secretion from pig pancreas, antrum, and nonantral stomach. Endocrinology. 1988;123(4):2009-2013.

38. Hvidberg A, Nielsen MT, Hilsted J, Orskov C, Holst JJ. Effect of glucagon-like peptide-1 (proglucagon 78-107amide) on hepatic glucose production in healthy man. Metab Clin Exp. 1994;43(1):104-108.

39. Wettergren A, Schjoldager B, Mortensen PE, Myhre J, Christiansen J, Holst JJ. Truncated GLP-1 (proglucagon 78-107-amide) inhibits gastric and pancreatic functions in man. Dig Dis Sci. 1993;38(4):665-673.

40. Pi-Sunyer X, et al. A randomized, controlled trial of $3.0 \mathrm{mg}$ of liraglutide in weight management. 
N Engl J Med. 2015;373(1):11-22.

41. Nauck MA, Kleine N, Orskov C, Holst JJ, Willms B, Creutzfeldt W. Normalization of fasting hyperglycaemia by exogenous glucagon-like peptide 1 (7-36 amide) in type 2 (non-insulin-dependent) diabetic patients. Diabetologia. 1993;36(8):741-744.

42. Ritzel R, Orskov C, Holst JJ, Nauck MA. Pharmacokinetic, insulinotropic, and glucagonostatic properties of GLP-1 [7-36 amide] after subcutaneous injection in healthy volunteers. Diabetologia. 1995;38(6):720-725.

43. Deacon CF, Johnsen AH, Holst JJ. Degradation of glucagon-like peptide- 1 by human plasma in vitro yields an $\mathrm{N}$-terminally truncated peptide that is a major endogenous metabolite in vivo. JClin Endocrinol Metab. 1995;80(3):952-957.

44. Deacon CF, Nauck MA, Toft-Nielsen M, Pridal L, Willms B, Holst JJ. Both subcutaneously and intravenously administered glucagon-like peptide 1 are rapidly degraded from the $\mathrm{NH}$-terminus in type II diabetic patients and in healthy subjects. Diabetes. 1995;44(9):1126-1131.

45. Deacon CF, Knudsen LB, Madsen K, Wiberg FC, Jacobsen O, Holst JJ. Dipeptidyl peptidase IV resistant analogues of glucagon-like peptide-1 which have extended metabolic stability and improved biological activity. Diabetologia. 1998;41(3):271-278.

46. Deacon CF, Hughes TE, Holst JJ. Dipeptidyl peptidase IV inhibition potentiates the insulinotropic effect of glucagon-like peptide 1 in the anesthetized pig. Diabetes. 1998;47(5):764-769.

47. Holst JJ, Deacon CF. Inhibition of the activity of dipeptidyl-peptidase IV as a treatment for type 2 diabetes. Diabetes. 1998;47(11):1663-1670.

48. Zander M, Madsbad S, Madsen JL, Holst JJ. Effect of 6-week course of glucagon-like peptide 1 on glycaemic control, insulin sensitivity, and betacell function in type 2 diabetes: a parallel-group study. Lancet. 2002;359(9309):824-830.

49. Drucker DJ, Philippe J, Jepeal L, Habener JF. Glucagon gene 5'-flanking sequences promote islet cell-specific gene transcription. J Biol Chem. 1987;262(32):15659-15665.

50. Philippe J, Drucker DJ, Knepel W, Jepeal L, Misulovin Z, Habener JF. Alpha-cell-specific expression of the glucagon gene is conferred to the glucagon promoter element by the interactions of DNA-binding proteins. Mol Cell Biol. 1988;8(11):4877-4888.

51. Drucker DJ, Asa S. Glucagon gene expression in vertebrate brain. J Biol Chem. 1988;263(27):13475-13478.

52. Drucker DJ, Brubaker PL. Proglucagon gene expression is regulated by a cyclic AMP-dependent pathway in rat intestine. Proc Natl Acad SciUS A. 1989;86(11):3953-3957.

53. Lee YC, Asa SL, Drucker DJ. Glucagon gene 5 '-flanking sequences direct expression of SV 40 large $T$ antigen to the intestine producing carcinoma of the large bowel in transgenic mice. J Biol Chem. 1992;267(15):10705-10708.

54. Drucker DJ, Lee YC, Asa SL, Brubaker PL. Inhibition of pancreatic glucagon gene expression in mice bearing a subcutaneous glucagon-producing GLUTag transplantable tumor. Mol Endocrinol. 1992;6(12):2175-2184.

55. Drucker DJ, Jin T, Asa SL, Young TA, Brubaker PL. Activation of proglucagon gene transcrip- tion by protein kinase-A in a novel mouse enteroendocrine cell line. Mol Endocrinol. 1994;8(12):1646-1655.

56. Brubaker PL, Schloos J, Drucker DJ. Regulation of glucagon-like peptide-1 synthesis and secretion in the GLUTag enteroendocrine cell line. Endocrinology. 1998;139(10):4108-4114.

57. Ehrlich P, Tucker D, Asa SL, Brubaker PL, Drucker DJ. Inhibition of pancreatic proglucagon gene expression in mice bearing subcutaneous endocrine tumors. Am J Physiol. 1994; 267(5 pt 1):E662-E671.

58. Drucker DJ, Erlich P, Asa SL, Brubaker PL. Induction of intestinal epithelial proliferation by glucagon-like peptide 2. Proc Natl Acad Sci U S A 1996;93(15):7911-7916.

59. Buhl T, Thim L, Kofod H, Orskov C, Harling H, Holst JJ. Naturally occurring products of proglucagon 111-160 in the porcine and human small intestine. J Biol Chem. 1988;263(18):8621-8624.

60. Drucker DJ, et al. Regulation of the biological activity of glucagon-like peptide 2 in vivo by dipeptidyl peptidase IV. Nat Biotechnol. 1997;15(7):673-677.

61. Boushey RP, Yusta B, Drucker DJ. Glucagon-like peptide (GLP)-2 reduces chemotherapy-associated mortality and enhances cell survival in cells expressing a transfected GLP-2 receptor. Cancer Res. 2001;61(2):687-693.

62. Drucker DJ, Yusta B, Boushey RP, DeForest L, Brubaker PL. Human [Gly2] GLP-2 reduces the severity of colonic injury in a murine model of experimental colitis. Am J Physiol.1999; 276(1 pt 1):G79-G91.

63. Boushey RP, Yusta B, Drucker DJ. Glucagon-like peptide 2 decreases mortality and reduces the severity of indomethacin-induced murine enteritis. Am J Physiol. 1999;277(5 pt 1):E937-E947.

64. Brubaker PL, Izzo A, Hill M, Drucker DJ. Intestinal function in mice with small bowel growth induced by glucagon-like peptide-2. Am JPhysiol. 1997;272(6 pt 1):E1050-E1058.

65. Scott RB, Kirk D, MacNaughton WK, Meddings JB. GLP-2 augments the adaptive response to massive intestinal resection in rat. Am J Physiol. 1998;275(5 pt 1):G911-G921.

66. Jeppesen PB, et al. Glucagon-like peptide 2 improves nutrient absorption and nutritional status in short-bowel patients with no colon. Gastroenterology. 2001;120(4):806-815.

67. Drucker DJ, Yusta B. Physiology and pharmacology of the enteroendocrine hormone glucagon-like peptide-2. Annu Rev Physiol. 2014;76:561-583.

68. Jeppesen PB, et al. Teduglutide reduces need for parenteral support among patients with short bowel syndrome with intestinal failure. Gastroenterology. 2012;143(6):1473-1481.e3.

69. Scrocchi LA, et al. Glucose intolerance but normal satiety in mice with a null mutation in the glucagon-like peptide 1 receptor gene. Nat Med. 1996;2(11):1254-1258.

70. Li Y, Hansotia T, Yusta B, Ris F, Halban PA, Drucker DJ. Glucagon-like peptide-1 receptor signaling modulates $\beta$ cell apoptosis. J Biol Chem. 2003;278(1):471-478.

71. Yusta B, et al. GLP-1 receptor activation improves beta cell function and survival follow- ing induction of endoplasmic reticulum stress. Cell Metab. 2006;4(5):391-406.

72. Eng J, Kleinman WA, Singh L, Singh G, Raufman JP. Isolation and characterization of exendin- 4 , an exendin-3 analogue, from Heloderma suspectum venom. Further evidence for an exendin receptor on dispersed acini from guinea pig pancreas. J Biol Chem. 1992;267(11):7402-7405.

73. Chen YE, Drucker DJ. Tissue-specific expression of unique mRNAs that encode proglucagonderived peptides or exendin 4 in the lizard. J Biol Chem. 1997;272(7):4108-4115.

74. Drucker DJ, et al. Exenatide once weekly versus twice daily for the treatment of type 2 diabetes: a randomised, open-label, non-inferiority study. Lancet. 2008;372(9645):1240-1250.

75. Drucker DJ. The cardiovascular biology of glucagon-like peptide-1. Cell Metab. 2016;24(1):15-30.

76. Fujita H, et al. The protective roles of GLP-1R signaling in diabetic nephropathy: possible mechanism and therapeutic potential. Kidney Int. 2014;85(3):579-589.

77. Koehler JA, et al. GLP-1R agonists promote normal and neoplastic intestinal growth through mechanisms requiring Fgf7. Cell Metab. 2015;21(3):379-391.

78. Ban K, Noyan-Ashraf MH, Hoefer J, Bolz SS, Drucker DJ, Husain M. Cardioprotective and vasodilatory actions of glucagon-like peptide 1 receptor are mediated through both glucagon-like peptide 1 receptor-dependent and -independent pathways. Circulation. 2008;117(18):2340-2350.

79. Pujadas G, Drucker DJ. Vascular biology of glucagon receptor superfamily peptides: mechanistic and clinical relevance. Endocr Rev 2016;37(6):554-583.

80. Noyan-Ashraf MH, et al. GLP-1R agonist liraglutide activates cytoprotective pathways and improves outcomes after experimental myocardial infarction in mice. Diabetes. 2009;58(4):975-983.

81. Kim M, et al. GLP-1 receptor activation and Epac2 link atrial natriuretic peptide secretion to control of blood pressure. Nat Med. 2013;19(5):567-575

82. Yusta B, et al. GLP-1 receptor (GLP-1R) agonists modulate enteric immune responses through the intestinal intraepithelial lymphocyte (IEL) GLP-1R. Diabetes. 2015;64(7):2537-2549.

83. Pfeffer MA, et al. Lixisenatide in patients with type 2 diabetes and acute coronary syndrome. N Engl J Med. 2015;373(23):2247-2257.

84. Holman RR, et al. Effects of once-weekly exenatide on cardiovascular outcomes in type 2 diabetes. N Engl J Med. 2017;377(13):1228-1239.

85. Marso SP, et al. Semaglutide and cardiovascular outcomes in patients with type 2 diabetes. $N$ Engl JMed. 2016;375(19):1834-1844.

86. Marso SP, et al. Liraglutide and cardiovascular outcomes in type 2 diabetes. $N$ Engl J Med. 2016;375(4):311-322.

87. Kaul S. Mitigating cardiovascular risk in type 2 diabetes with antidiabetes drugs: a review of principal cardiovascular outcome results of EMPA-REG OUTCOME, LEADER, and SUSTAIN-6 Trials. Diabetes Care. 2017;40(7):821-831.

88. Bak MJ, et al. Specificity and sensitivity of commercially available assays for glucagon-like peptide-1 (GLP-1): implications for GLP-1 measure- 
ments in clinical studies. Diabetes Obes Metab. 2014;16(11):1155-1164.

89. Hartmann B, Johnsen AH, Orskov C, Adelhorst K, Thim L, Holst JJ. Structure, measurement, and secretion of human glucagon-like peptide-2. Peptides. 2000;21(1):73-80.

90. Panjwani N, et al. GLP-1 receptor activation indirectly reduces hepatic lipid accumulation but does not attenuate development of atherosclerosis in diabetic male ApoE(-/-) mice. Endocrinology. 2013;154(1):127-139.

91. Reimann F, Habib AM, Tolhurst G, Parker HE, Rogers GJ, Gribble FM. Glucose sensing in L cells: a primary cell study. Cell Metab. 2008;8(6):532-539.

92. Petersen N, et al. Generation of L cells in mouse and human small intestine organoids. Diabetes.
2014;63(2):410-420.

93. Athauda D, et al. Exenatide once weekly versus placebo in Parkinson's disease: a randomised, double-blind, placebo-controlled trial [published online ahead of print August 3, 2017]. Lancet. https://doi.org/10.1016/S01406736(17)31585-4.

94. Davies M, Pieber TR, Hartoft-Nielsen ML, Hansen OKH, Jabbour S, Rosenstock J. Effect of oral semaglutide compared with placebo and subcutaneous semaglutide on glycemic control in patients with type 2 diabetes: a randomized clinical trial. JAMA. 2017;318(15):1460-1470.

95. Finan B, et al. A rationally designed monomeric peptide triagonist corrects obesity and diabetes in rodents. Nat Med. 2015;21(1):27-36.

96. Tschöp MH, et al. Unimolecular polypharma- cy for treatment of diabetes and obesity. Cell Metab. 2016;24(1):51-62.

97. Serre V, Dolci W, Scrocchi LA, Drucker DJ, Efrat S, Thorens B. Exendin-(9-39) as an inverse agonist of the murine GLP-1 receptor. Endocrinolo$g y$. 1998;139(11):4448-4454.

98. Salehi M, Gastaldelli A, D’Alessio DA. Blockade of glucagon-like peptide 1 receptor corrects postprandial hypoglycemia after gastric bypass. Gastroenterology. 2014;146(3):669-680.e2.

99. Madsbad S, Dirksen C, Holst JJ. Mechanisms of changes in glucose metabolism and bodyweight after bariatric surgery. Lancet Diabetes Endocrinol. 2014;2(2):152-164.

100.Drucker DJ. Incretin action in the pancreas: potential promise, possible perils, and pathological pitfalls. Diabetes. 2013;62(10):3316-3323. 